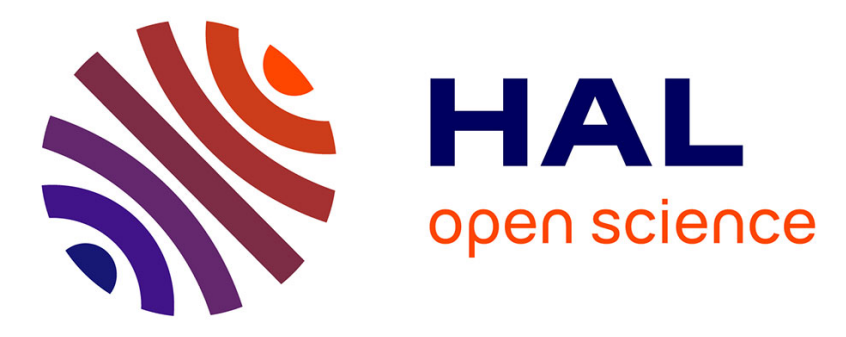

\title{
Synthesis of sex steroids in final oocyte maturation and induced ovulation in female Eurasian perch, Perca fluviatilis
}

Hervé Migaud, R. Mandiki, J.N. Gardeur, Alexis Fostier, Patrick Kestemont, P. Fontaine

\section{To cite this version:}

Hervé Migaud, R. Mandiki, J.N. Gardeur, Alexis Fostier, Patrick Kestemont, et al.. Synthesis of sex steroids in final oocyte maturation and induced ovulation in female Eurasian perch, Perca fluviatilis. Aquatic Living Resources, 2003, 16 (4), pp.380-388. 10.1016/S0990-7440(03)00079-2 . hal-02678590

\section{HAL Id: hal-02678590 \\ https: / hal.inrae.fr/hal-02678590}

Submitted on 31 May 2020

HAL is a multi-disciplinary open access archive for the deposit and dissemination of scientific research documents, whether they are published or not. The documents may come from teaching and research institutions in France or abroad, or from public or private research centers.
L'archive ouverte pluridisciplinaire HAL, est destinée au dépôt et à la diffusion de documents scientifiques de niveau recherche, publiés ou non, émanant des établissements d'enseignement et de recherche français ou étrangers, des laboratoires publics ou privés.

$$
\text { Copyright }
$$




\title{
Synthesis of sex steroids in final oocyte maturation and induced ovulation in female Eurasian perch, Perca fluviatilis
}

\author{
Hervé Migaud $^{\text {a,d }}$, Robert Mandiki ${ }^{\text {b }}$, Jean-Noël Gardeur ${ }^{\mathrm{a}}$, Alexis Fostier ${ }^{\mathrm{c}}$, \\ Patrick Kestemont ${ }^{\mathrm{b}}$, Pascal Fontaine ${ }^{\mathrm{a}, *}$ \\ ${ }^{a}$ Laboratoire de Sciences Animales, INRA-INPL-UHP, Nancy 1, MAN, 34, rue Sainte-Catherine, 54000 Nancy, France \\ ${ }^{b}$ Unité de Recherches en Biologie des Organismes, Facultés Universitaires Notre-Dame de la Paix, 61, rue de Bruxelles, 5000 Namur, Belgium \\ ${ }^{c}$ Laboratoire de Physiologie des Poissons, Campus de Beaulieu, INRA, Rennes 35042 cedex, France \\ ' Institute of Aquaculture, University of Stirling, Stirling, UK
}

Received 26 March 2003; accepted 23 June 2003

\begin{abstract}

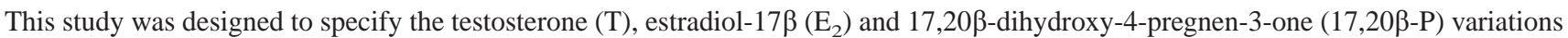
during the pre-ovulatory period in female Eurasian perch, Perca fluviatilis, and also examine the ovarian synthesis of 17,20 $\beta$-P and

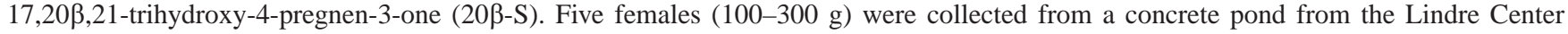
(Moselle, France) between March and April 1999, three times a week, and sex steroids measured. Two females were also collected from the Lindre pond on three dates (18 February, 14 and 23 March) for an in vitro study. Significant plasma 17,20 $\beta$-P peaks were measured for the first time in this species reaching $3.5 \mathrm{ng} \mathrm{ml}^{-1}$. However, the synthesis and release of 17,20 $\beta$-P in blood seems to not be synchronized with the final maturation and ovulation stages. The in vitro study showed that ovaries at the pre-ovulatory stage produce some $17,20 \beta-\mathrm{P}$ but no $20 \beta-\mathrm{S}$ from a tritiated precursor $\left(17-\mathrm{P}_{-}{ }^{3} \mathrm{H}\right) \cdot 17,20 \beta-\mathrm{P}$ is produced after $30 \mathrm{~min}$ and is still present in the medium after $2 \mathrm{~h}$ of incubation, but is no longer detectable after $4 \mathrm{~h}$. Some other non-identified compounds were synthesized at this stage suggesting that 17,20 $-\mathrm{P}$ was quickly metabolized. Moreover, the plasma level increases, observed in spawned females suggest that this steroid might be involved in the oviposition process. These results suggest a role for 17,20 $\beta$-P in the final stages of oocyte development.
\end{abstract}

(C) 2003 Éditions scientifiques et médicales Elsevier SAS and Ifremer/IRD/Inra/Cemagref. All rights reserved.

\section{Résumé}

Synthèse des stéroïdes sexuels au cours de la maturation finale des ovocytes et l'induction de l'ovulation chez la perche commune femelle, Perca fluviatilis. Une étude a été conduite dans le but de préciser les variations de testostérone $(\mathrm{T})$, d'œstradiol $\left(\mathrm{E}_{2}\right)$ et de

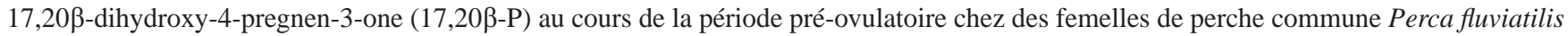

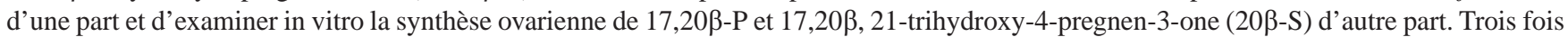
par semaine, 5 femelles (100-300 g) ont été capturées dans l'étang de Lindre (Moselle, France) sur la période de mars-avril 1999 et leurs teneurs en hormones stéroïdes sexuelles dosées. Deux femelles supplémentaires ont été capturées, les 18 février, 14 et 23 mars, pour l'étude in vitro. Dans le plasma, des pics significatifs de la teneur en 17,20 $-\mathrm{P}\left(3,5 \mathrm{ng} \mathrm{ml}^{-1}\right)$ ont été mesurés pour la première fois. Cependant, la synthèse et la libération de 17,20 $\beta$-P dans le sang ne semblent pas synchrones avec les stades de la maturation ovocytaire et l'ovulation. L'étude

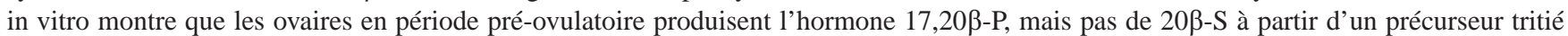
(17-P- $\left.{ }^{3} \mathrm{H}\right)$. La 17,20 3 -P est produite au bout d'une demi-heure et est encore présente dans le milieu après $2 \mathrm{~h}$ d'incubation, mais n'est plus détectée après $4 \mathrm{~h}$ d'incubation. D'autres composés non identifiés sont synthétisés à ce stade ce qui suppose que la 17,20 3 -P est rapidement métabolisée. Chez les femelles qui ont pondu, la teneur en 17,20ß-P dans le plasma est élevée ; par conséquent, ce stéroïde pourrait être impliqué dans le processus de l'oviposition. Ces résultats confirment le rôle de la 17,20ß-P dans les phases finales du développement ovocytaire.

(C) 2003 Éditions scientifiques et médicales Elsevier SAS and Ifremer/IRD/Inra/Cemagref. All rights reserved.

Keywords: Ovarian steroidogenesis; Maturation-inducing steroid; Eurasian perch

\footnotetext{
* Corresponding author.

E-mail address: pascal.fontaine @1sa-man.uhp-nancy.fr (P. Fontaine).
} 


\section{Introduction}

Reproduction of Eurasian perch, Perca fluviatilis, has received little attention contrary to other percids such as yellow perch, Perca flavescens, (Dabrowski et al., 1996) and walleye Stizostedion vitreum (Malison et al., 1994; Malison and Held, 1996). Limited data exists concerning the endocrine control of the reproductive cycle of this species, especially during the final maturation and ovulation stages. There is only limited data relative to body composition variations (Craig, 1977), sexual maturation (Treasurer and Holliday, 1981), variation of the gonadosomatic index (Le Cren, 1951; Jamet and Desmolles, 1994), global seasonal changes of plasma sex steroids in the natural habitat (Sulistyo et al., 1998, 2000), and out-of-season conditions (Migaud et al., 2002).

As for the pre-ovulatory changes in teleosts with group synchronous ovarian development, the plasma estradiol-17 $\beta$ $\left(\mathrm{E}_{2}\right)$ and testosterone $(\mathrm{T})$ levels, high during vitellogenesis, decrease when the maturation-inducing steroid (MIS), such as $17,20 \beta$-dihydroxy-4-pregnen-3-one (17,20 $\beta$-P), increases just after the gonadotropin surge (Fostier et al., 1978, 1981; Breton et al., 1983; Kime, 1993; Mylonas et al., 1998). Besides, a T peak was sometimes reported during the oocyte maturation period (Kime, 1993; Borg, 1994; Mylonas et al., 1998). The $\mathrm{E}_{2}$ concentration is low at hydratation and ovulation stages among several perciforms such as white perch, Morone americana, (King et al., 1995), white bass, Morone chrysops (Berlinsky et al., 1995; Mylonas et al., 1998), striped bass, Morone saxatilis (Berlinsky and Specker, 1991; Mylonas et al., 1997a) and sea bass, Dicentrarchus labrax (Prat et al., 1990; Asturiano et al., 2000). As far as Eurasian perch is concerned, Sulistyo et al. (1998) showed that plasma $\mathrm{E}_{2}$ and $\mathrm{T}$ increased prior to spawning whereas the plasma $17,20 \beta-P$ profile did not display any significant peak with levels ranging from 0.2 to $0.5 \mathrm{ng} \mathrm{ml}^{-1}$. These results suggest that either another MIS in Eurasian perch could be involved, or the peaks would be so pulsatory that they would have not been detected during sampling.

Two types of steroids have been identified in different species as MISs: 17,20 $\beta-\mathrm{P}$ in several species, such as in rainbow trout, Oncorhynchus mykiss (Fostier et al., 1973; Jalabert et al., 1977; Fostier and Jalabert, 1986), amago salmon, Oncorhynchus rhodurus (Patino and Thomas, 1990), yellow perch (Goetz and Bergman, 1978; Goetz and Theofan, 1979), plaice, Pleuronectes platessa (Scott and Canario, 1992) and tilapia, Oreochromis mossambicus (Rocha and Ries-Henriques, 1998), and 17,20ß,21trihydroxy-4-pregnen-3-one (20 $\beta$-S) in species such as spotted seatrout, Cynoscion nebulosus (Thomas and Trant, 1989; Pinter and Thomas, 1999), white bass (King et al., 1995), turbot, Psetta maxima (Mugnier et al., 1997) and Atlantic croaker, Micropogonias undulates (Trant et al., 1986; Patino and Thomas, 1990). Several in vitro experiments using ovarian follicles from various teleost species showed that these two steroids are effective inductors of final oocyte maturation
(Jalabert, 1976; Goetz and Bergman, 1978; Scott and Canario, 1987; Pinter and Thomas, 1999). Studies on moronid fish, such as M. americana (King et al., 1995) or M. chrysops (Mylonas et al., 1997b), showed that the plasma levels of both 17,20 $\beta-\mathrm{P}$ and $20 \beta-\mathrm{S}$ increased during the final maturational stages, suggesting a role for both steroids during stage 4 (peripheral germinal vesicle, GV), ovulation and spawning, whereas plasma $E_{2}$ and $T$ levels decreased. The same phenomenon was also observed in in vitro experiments with ovarian fragments. Furthermore, studies on other teleost species such as black sea bass, Centropristis striata, suggested

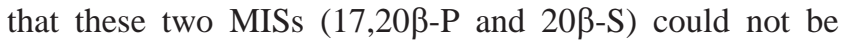
involved in the final maturational process (Cerda et al., 1996).

In Eurasian perch, sex steroid variations during the preovulatory period and the hormonal control of final oocyte maturation, ovulation and spawning are little documented. The MIS is still unknown in this species but is likely to be $17,20 \beta-\mathrm{P}$, as it has been already shown in the yellow perch (same genus). This study focused on the hormonal control of the last stages of the reproductive cycle in female Eurasian perch and was performed (1) so as to clarify the androgen and estrogen ( $\mathrm{T}$ and $\mathrm{E}_{2}$ ) variations during the pre-ovulatory period and (2) to examine the ovarian potential synthesis of $17,20 \beta-\mathrm{P}$ and $20 \beta-\mathrm{S}$ during the pre-ovulatory stages.

\section{Materials and methods}

\subsection{Fish}

Fish (100 kg of fish in total) were harvested from the Lindre pond (surface area $62 \times 10^{5} \mathrm{~m}^{2}$, volume $12 \times 10^{6} \mathrm{~m}^{3}$, altitude $210 \mathrm{~m}$, latitude $48^{\circ} 49^{\prime} \mathrm{N}$, longitude $6^{\circ} 43^{\prime} \mathrm{E}$ ), in Moselle, France, and were maintained in an external outside concrete pond. Female perch were collected at 10:00 h three times a week at 2-day intervals, from early March to late April 1999. Four to seven females were caught at each sampling date (154 females sampled in total), and only maturing females, recognized by swollen abdomen and genital papilla, were considered. Further sampling was carried out between March and April 2000 to investigate the in vitro synthesis of $17,20 \beta-P$ and $20 \beta-S$ by ovaries. Six females were collected at the Lindre center at three different dates (two at each date, 18 February, 14 and 23 March) for an in vitro study. First spawning was observed on 10 April.

\subsection{Plasma sampling}

Immediately after capture, fish were anaesthetized in a 2-phenoxyethanol solution ( $1 \mathrm{ml}^{-1}$, SIGMA), then individually weighed (body weight $\mathrm{BW} \pm 0.1 \mathrm{~g}$ ), measured for standard length (SL $\pm 1 \mathrm{~mm}$ ), blood sampled and dissected. Fish averaged $175 \pm 72 \mathrm{~g}(n=5$, from 77 to $392 \mathrm{~g})$ in weight and $223 \pm 26 \mathrm{~mm}$ in length (mean \pm S.D.). A $1 \mathrm{ml}$-blood sample was taken from the heart using a heparinized syringe. Blood was then centrifuged at $4000 \mathrm{rpm}(3400 \times g)$ for $25 \mathrm{~min}$ and 
plasma stored in vials at $-25^{\circ} \mathrm{C}$ until assay. The gonads, liver and viscera were entirely removed and weighed $( \pm 0.01 \mathrm{~g})$.

For the in vitro study, the gonads were removed and approximately $1 \mathrm{~g}$ of each ovary, taken from the middle, was placed in $20 \mathrm{ml}$ glass flasks containing $5 \mathrm{ml}$ of an incubation medium, L15 medium Leibovitz (with L-glutamine, SIGMA).

The gonadosomatic index, $I_{\mathrm{G}}(\%)$ was calculated as follows: $I_{\mathrm{G}}=100 \times(\mathrm{GW} / \mathrm{BW})$, where $\mathrm{GW}$ is weight of ovary and BW is body weight in gram $(\mathrm{g})$.

\subsection{Ovarian histology}

A fragment from the ovary of each female was removed and fixed in Bouin Holland's solution and embedded in Paraplast for histological examination. The tissues were subsequently cut to a $5 \mu \mathrm{m}$ thickness, and stained with a trichrome method according to Rinchard et al. (1996): Regaud's haematoxyline at $57^{\circ} \mathrm{C}$, phloxine and light green. The development stages of the oocyte were determined on a single ovarian section per fish, according to Malservisi and Magnin (1968) and Treasurer and Holliday (1981). Oocytes percentage at each stage were not determined, as oocyte development in perch is synchronous. However, two different oocyte stages can coexist at some stage and a female was, therefore, assigned to a category depending on the most abundant stage observed. Seven different oocyte stages were observed as follows:

- Stage 1: ovary containing previtellogenic oocytes.

- Stage 2: ovary with vitellogenic oocytes characterized by the yolk globules, and peripheral yolk vesicles. The nucleus is in a central position.

- Stage 3: yolk globules form a homogenous mass with some lipid droplets inside the cytoplasm. The nucleus, i.e. GV starts to migrate from its central position to the periphery (pre-migrating GV, Fig. 1a).

- Stage 4: GV completes its migration towards the periphery (animal pole) and a large lipid droplet (or sometimes several) is located at the vegetative pole (Fig. 1b).

- Stage 5: GV breaks down (Fig. 1c).

- Stage 6: ovulation stage characterized by vitellus and a large lipid droplet (Fig. 1d).

- Stage 7: oviposition, the emptied ovary contains primary oocytes.

\subsection{Radioimmunoassays}

Plasma concentrations of T, $\mathrm{E}_{2}$ and 17,20 $\beta$-P were determined using radioimmunoassay (RIA) analysis according to Fostier and Jalabert (1986), following two extractions with cyclohexane/ethylacetate $(\mathrm{v} / \mathrm{v})$. The extractions were performed on $50 \mu \mathrm{l}$ of plasma for each steroid. Samples were assayed in duplicate and the steroid standards in triplicate. Fostier and Jalabert (1986) described the cross reactivity of antiserum with a variety of common steroids. $\mathrm{T}, \mathrm{E}_{2}$ and 17,20ß-P intra-assay coefficients of variation were 5.9, 7.5 and $9.6 \%(n=14)$, respectively. All samples were analyzed in
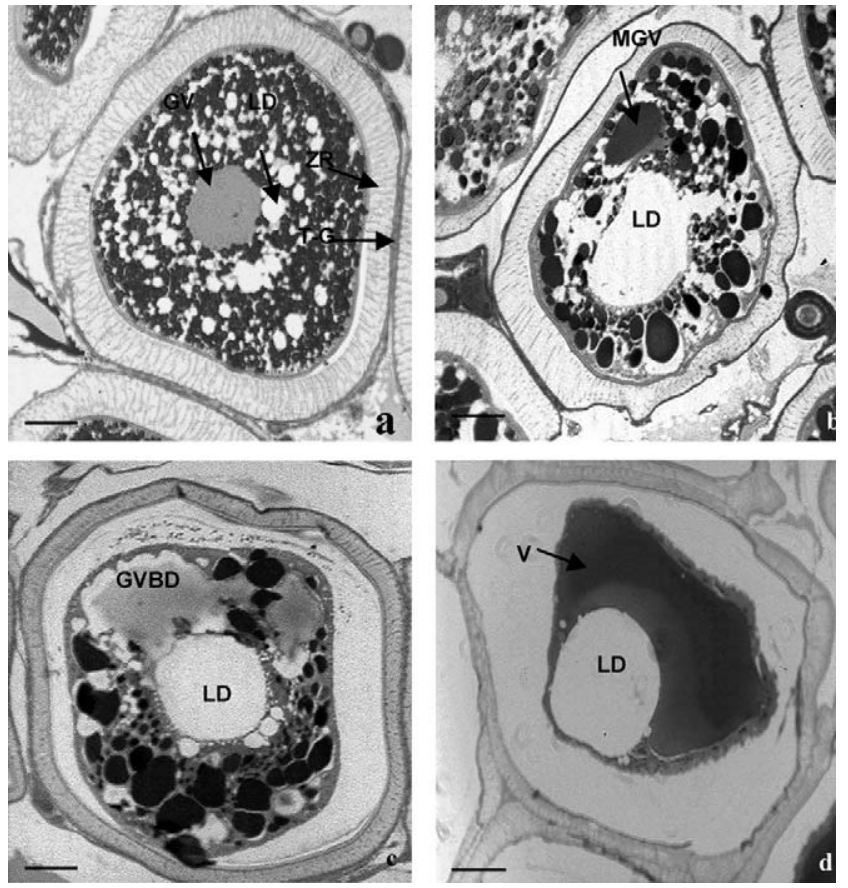

Fig. 1. Ova development stages in female Eurasian perch $P$. fluviatilis during the pre-ovulatory period (March-April 1999). a: specimen sampled on 7 April (×100): stage 3; b: 14 April ( $\times 100)$ : stage 4; c: 21 April ( $\times 100)$ : stage 5; d: 23 April $(\times 100)$ : stage 6 . Scale $=100 \mu \mathrm{m}$. GV: germinal vesicle; LD: lipid droplet; T-G: thecal and granulosal walls; ZR: zona radiata (chorion with micro-villosity); mGV: migrated germinal vesicle; GVBD: germinal vesicle breakdown; V: vitellus.

a single RIA for each steroid. The detection limits were $7.5 \mathrm{pg} \mathrm{ml}^{-1}$ for T, $\mathrm{E}_{2}$ and 17,20ß-P.

\subsection{In vitro steroid production}

Incubations $(5 \mathrm{ml})$ were initiated by addition of $370 \mathrm{kBq}$ of $\left[1,2,6,7-{ }^{3} \mathrm{H}\right] 17$-hydroxy-4-pregnen-3-one as the tritiated precursor $\left(17-\mathrm{P}_{-}{ }^{3} \mathrm{H}\right.$ Amersham Pharmacia Biotech, s.a. = $2.25 \mathrm{TBq} \mathrm{mmol}^{-1}$ ). After $30 \mathrm{~min}, 2$ and $4 \mathrm{~h}$ of incubation at $9-11{ }^{\circ} \mathrm{C}$, the metabolism of the tritiated precursor was stopped by adding $40 \mu \mathrm{g}$ of the non-labeled precursor in 100 $\mu \mathrm{l}$ of ethanol. The medium and the tissue were immediately frozen and stored at $-20^{\circ} \mathrm{C}$ until assay.

The steroids were extracted from the media three times with $4 \mathrm{ml}$ of cyclohexane; $20 \mu \mathrm{g}$ of standard steroids, $17,20 \beta-\mathrm{P}$ and 17,203,21-P were added to the organic phase. The organic phases removed from the extractions were vacuum dried and the extracts dissolved in $200 \mu \mathrm{l}$ of ethanol. Ethanol extracts were chromatographed by thin layer chromatography (TLC) using Merck $620 \mathrm{~F}_{254} 20$-cm silica plates (Merck ref. 10583) with concentration zones. Plates were developed twice in a saturated atmosphere of solvent, benzene:acetone $(80: 20, \mathrm{v} / \mathrm{v})$ at room temperature $\left(20-22{ }^{\circ} \mathrm{C}\right)$. Standard steroids were visualized with the help of a UV lamp $(\lambda=254 \mathrm{~nm})$ and radioactive peaks were detected with a mono-dimensional gas ionization scanner (Packard 7222).

The migration zones corresponding to the two reference

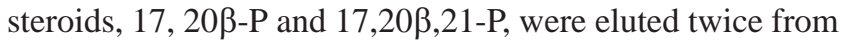


the bands of the silica plates with $5 \mathrm{ml}$ of dichloromethane:methanol (90:10). Following centrifugation $1000 \times g$ for $10 \mathrm{~min}$, the supernatants were pooled and vacuum dried before finally being dissolved in $200 \mu \mathrm{l}$ of ethanol. Extracts were then analyzed through reverse-phase HPLC (High Performance Liquid Chromatography, Constametric 3000, LDC) using a $5 \mu \mathrm{C} 18$ Nucleosil 100 column at a

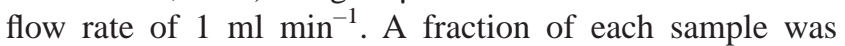
diverted to a radiochemical detector. The resulting signals (spectrophotometric and radiochemical) were recorded and analyzed with the help of a computer (Flo-one program, Packard).

\subsection{Statistical analysis}

Statistical analyses were performed using the mixed procedure with repeated time, as data between sampling points were related (SAS software, Littell et al., 1996), for unbalanced analysis of variance (ANOVA) without any treatment effects. The individual 17,20 $\beta$-P levels at various oocyte stages were analyzed using an unbalanced one-way ANOVA (SAS, Mixed procedure). The minimum level of significance was set at $P \leq 0.05$ and the coefficient of variation of the root mean square error (CV RMSE) is indicated for each graph. All quantitative data are expressed as Lsmeans (adjusted means) \pm standard error (S.E.) and were compared to the adjusted Bonferroni test. NS and S stand, respectively, for not significant and significant.

\section{Results}

\subsection{Ovarian development}

In 1999, the $I_{\mathrm{G}}$ rose gradually from March until the spawning period in late April, when it reached its maximum of $23.8 \pm 1.2 \%$ (mean \pm S.E., Fig. 2). The sudden decrease observed on 26 April corresponded to the beginning of the

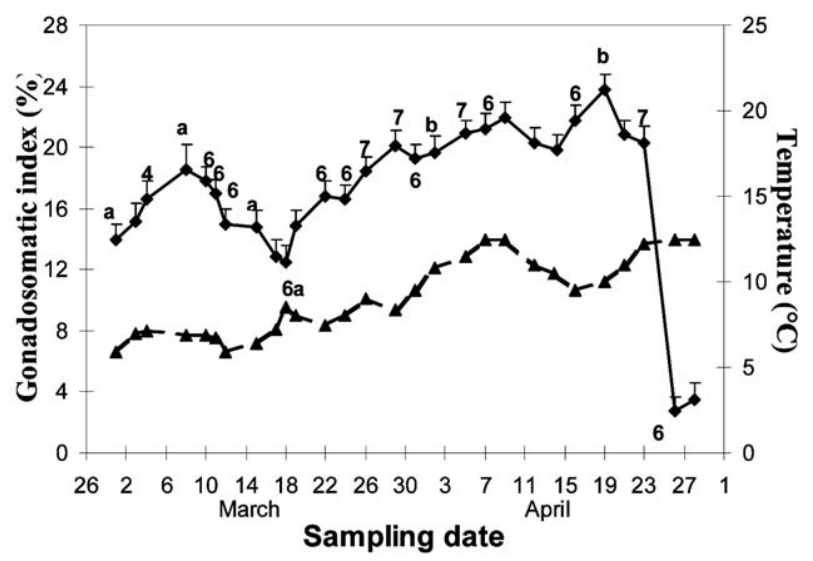

Fig. 2. Water temperature ( $\boldsymbol{\Delta}$, dashed line) in Lindre pond and gonadosomatic index $\left(I_{\mathrm{G}},>\right.$, mean + S.E., $\left.n=5\right)$ in $P$. fluviatilis during the pre-ovulatory period. Numbers indicate sample size (when different to 5) and the different letter indicate mean values significantly different $(P<0.05$, only the main differences were indicated). CV RMSE $=14 \%$.

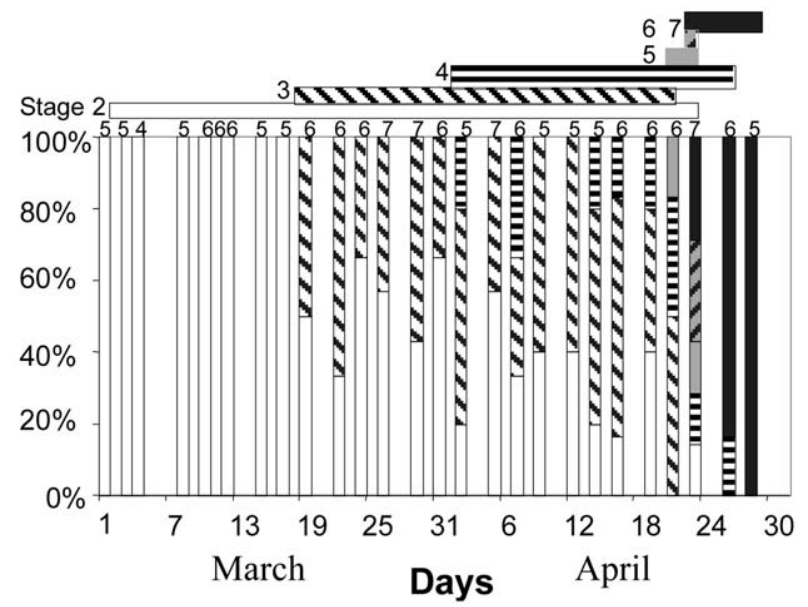

Fig. 3. Oogenesis stages observed in $P$. fluviatilis during the pre-ovulatory period. Numbers above each element indicate sample size. Stage 2: ovaries with vitellogenic oocytes; stage 3: pre-migrating GV; stage 4: oocytes with peripheral GV; stage 5: GVBD; stage 6: ovulation; stage 7: spawning.

spawning period. The temperature increased progressively from 5.9 to $12.5{ }^{\circ} \mathrm{C}$ on 26 April, when the perch started to spawn. In 2000, the $I_{\mathrm{G}}$ averaged $16.9 \pm 0.5,17.8 \pm 0.4$ and $21.8 \pm 0.4 \%$ (mean \pm S.E.) for the three sampling dates (in vitro incubation), respectively.

The immature ovaries sampled with previtellogenic oocytes were not considered in this study. In March, all the sampled ovaries contained only vitellogenic oocytes. The first oocytes in stage 3 (Fig. 1a) were observed from 19 March (Fig. 3). Then, the first oocytes with a peripheral GV (Fig. 1b) were sampled on 2 April (Fig. 2) and among the four females sampled, three of them presented migrated $\mathrm{GV}$. From 2 to 18 April, broodstock at stages 2-4 were observed with a higher proportion of fish at the late vitellogenesis stage (stage 3: pre-migrating GV), which represent 33-70\% of the stages observed (Fig. 3). The germinal vesicle break down (GVBD) stage (Figs. 1c and 3) was observed for the first time in ovaries sampled on 21 April and the ovulation stage on 23 April (Figs. 1d and 3). However, the occurrence of these stages was very low among the different samples. The first oviposition (stage 7) was recorded on 23 April (Fig. 3).

\subsection{Plasma steroid levels}

\subsubsection{Estradiol}

The plasma $\mathrm{E}_{2}$ levels began to rise in mid-March (Fig. 4a) and one significant peak was detected throughout the sampling period in females sampled on 19 April (3.6 $\pm 0.6 \mathrm{ng}$ $\mathrm{ml}^{-1}$, Lsmean, $P<0.05$ ); another peak appeared on 19 March $\left(3.3 \pm 0.6 \mathrm{ng} \mathrm{ml}^{-1}\right)$ but not significant. The mean plasma levels of $E_{2}$ at various stages of development (Fig. 5a) ranged from detection to $1.2 \pm 0.2 \mathrm{ng} \mathrm{ml}^{-1}$, but no significant differences between the several stages were observed because of some very high variation and different sample sizes. Nevertheless, the plasma levels as well as the intra-stage variability seemed to decrease the more the oocytes were at an advanced stage, but the size of the samples decreased. The highest 


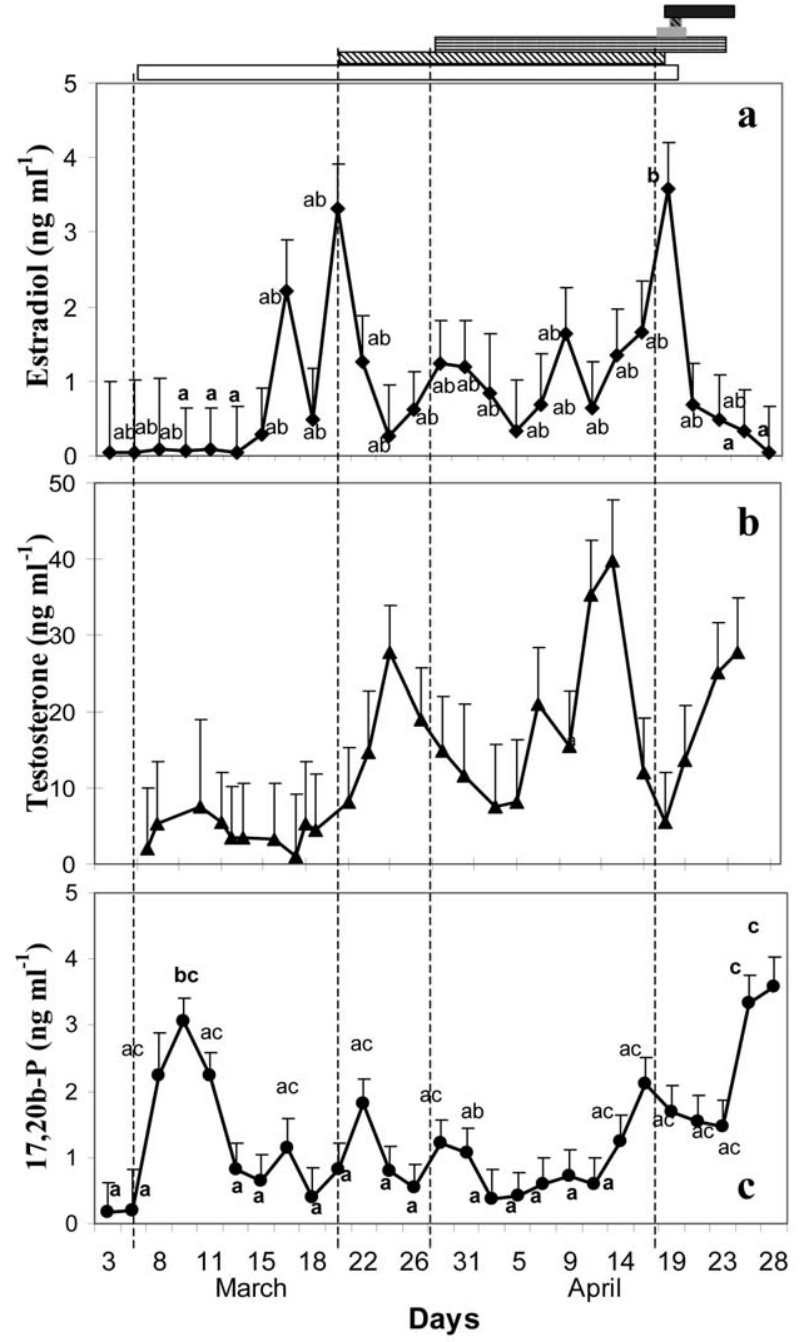

Fig. 4. Plasma levels (mean + S.E.) of estradiol-17 $\beta$ (a), testosterone (b) and $17,20 \beta-\mathrm{P}$ (c) in $P$. fluviatilis during the pre-ovulatory period. CV RMSE = $155 \%, 40 \%$ and $69 \%$, respectively, for $\mathrm{E}_{2}, \mathrm{~T}$ and $17,20 \beta-\mathrm{P}$.

individual values were observed in fish with oocytes in stage 2 or $3\left(1.2 \pm 0.2\right.$ and $1.1 \pm 0.3 \mathrm{ng} \mathrm{ml}^{-1}$, respectively).

\subsubsection{Testosterone}

Plasma T levels (Fig. 4b) were observed to follow the same pattern as $\mathrm{E}_{2}$, although no statistically significant variations were shown, with low values up to 22 March, ranging from 2.8 to $7.8 \mathrm{ng} \mathrm{ml}^{-1}$. Levels appear to be higher in late March $\left(27.7 \pm 6.1 \mathrm{ng} \mathrm{ml}^{-1}\right)$ and mid April $(39.4 \pm 8.1 \mathrm{ng}$ $\left.\mathrm{ml}^{-1}\right)$; the first "peak" was slightly delayed and the second "peak" advanced, compared to those observed for $\mathrm{E}_{2}$. However, high variability between females sampled at the same period concealed the observation of significant differences. Fig. 5b shows the mean plasma concentrations for each stage of oocyte development. Mean plasma T levels display large variations between the different stages observed. The concentrations are similar at stages $2-4(12.9 \pm 2.6,13.8 \pm 2.9$ and $11.0 \pm 5.0 \mathrm{ng} \mathrm{ml}^{-1}$, respectively). The $\mathrm{T}$ level is significantly higher at stage $7\left(24.2 \pm 8.0 \mathrm{ng} \mathrm{ml}^{-1}\right)$ than at stages 2 , 3 and 5. Levels measured at stage 6 are similar to those
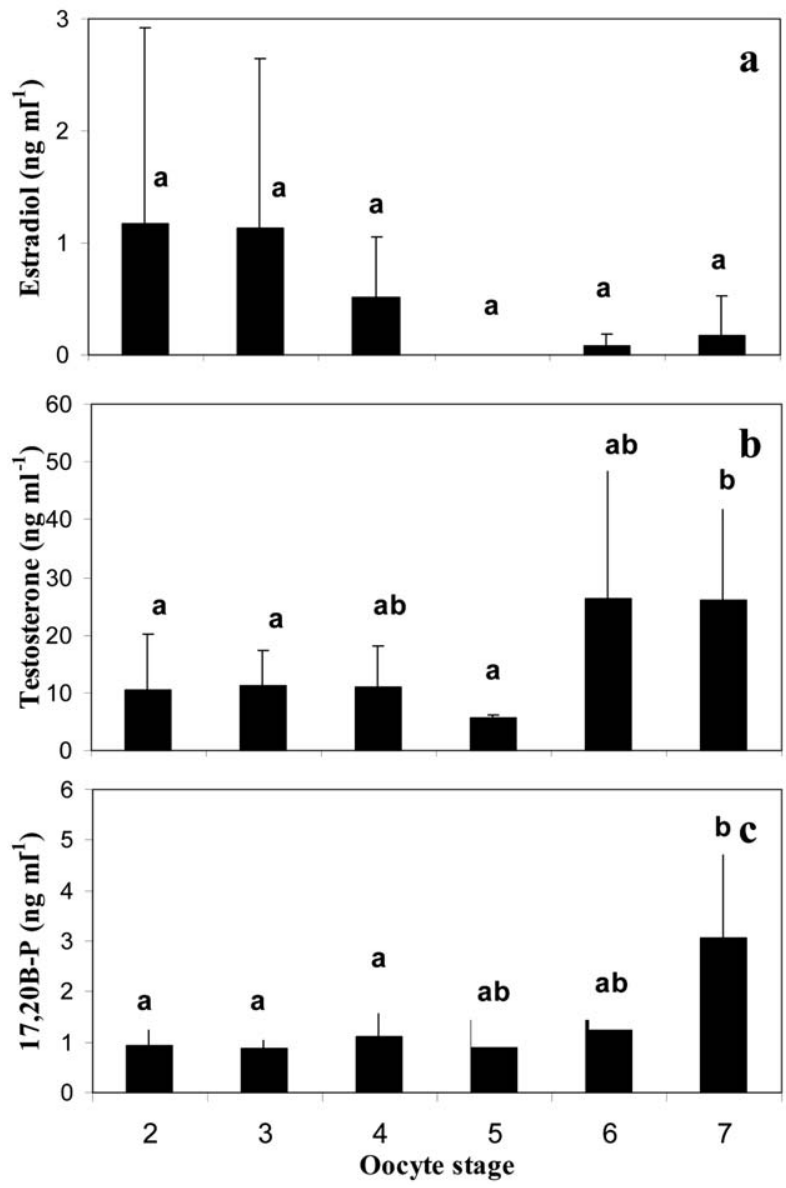

Fig. 5. Plasma levels (mean + S.E.) of estradiol-17 $\beta$ (a), testosterone (b) and 17,20ß-P (c) in P. fluviatilis during the pre-ovulatory period at various stages of development. Stage $2(n=43)$, vitellogenic oocytes; stage $3(n=22)$, pre-migrating $\mathrm{GV}$; stage $4(n=5)$, oocytes with peripheral $\mathrm{GV}$; stage 5 $(n=2)$, GVBD; stage $6(n=2)$, ovulation; stage $7(n=13)$, spawning. The different letter indicates mean values significantly different $(P<0.05)$. CV RMSE $=291 \%, 70 \%$ and $77 \%$, respectively, for $\mathrm{E}_{2}, \mathrm{~T}$ and $17,20 \beta-\mathrm{P}$.

observed at stage 7 , but not significantly different when compared to previous stages.

\subsection{3. $17,20 \beta-P$}

As far as $17,20 \beta-\mathrm{P}$ is concerned, the mean plasma levels (Fig. 4c) displayed two significant peaks. The first peak occurred in late winter with values of $3.1 \pm 0.4 \mathrm{ng} \mathrm{ml}^{-1}$ on 10 March. From 12 March to 2 April, plasma concentrations fluctuated slightly and dropped to a basic level of approximately $0.6 \mathrm{ng} \mathrm{ml} \mathrm{m}^{-1}$. Just before the spawning period, the 17,20 $\beta$-P levels increased significantly from 12 April to 27 and 28 April, and reached mean values of $3.4 \pm 0.4$ and $3.6 \pm$ $0.5 \mathrm{ng} \mathrm{ml}^{-1}$, respectively. These levels are significantly different from those measured from 10 March to 12 April, except for 22 March. The mean plasma levels of 17,20 $3-\mathrm{P}$ at various stages of development (Fig. 5c) ranged from $0.9 \pm 0.2$ (stage 3) to $3.0 \pm 0.2 \mathrm{ng} \mathrm{ml}^{-1}$ (stage 7). Plasma levels observed at stage 7 are significantly higher than those measured at stages 2-4, although individual values are very 


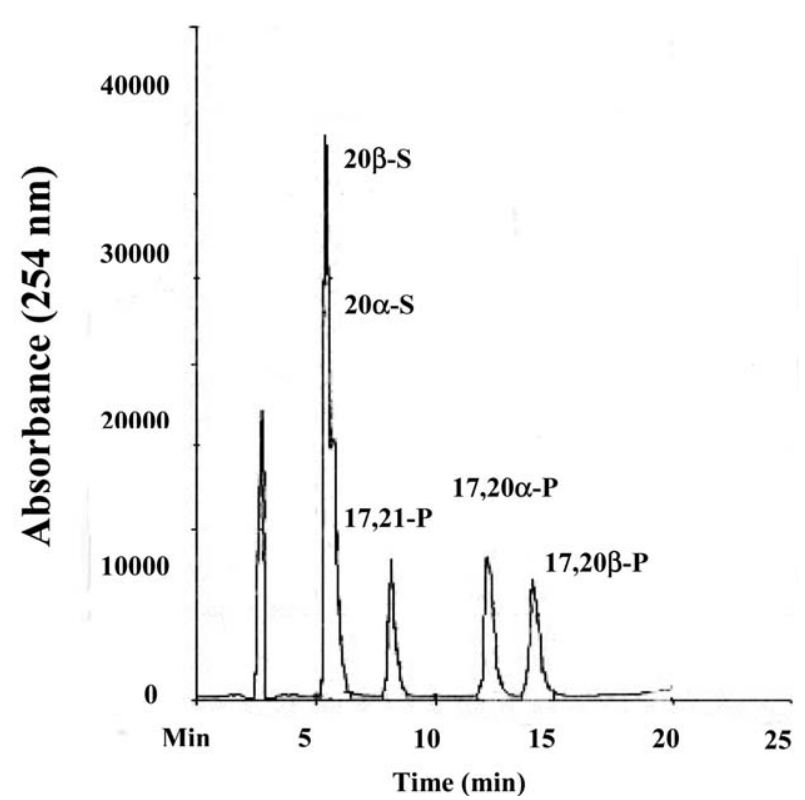

Fig. 6. HPLC chromatograms of standards steroids separated on a C-18 column and eluted with water:acetonitrile:methanol at a flow rate of $0.5 \mathrm{ml}$ $\mathrm{min}^{-1}$. The retention times are as follow: $5.5 \mathrm{~min}(17,20 \alpha, 21-\mathrm{P}$ and 17,20 $\beta)$, $8.0 \mathrm{~min}(17,21-\mathrm{P}), 12.5 \mathrm{~min}(17,20 \alpha-\mathrm{P})$ and $14.5 \mathrm{~min}(17,20 \beta-\mathrm{P})$.

variable, ranging from 1 to almost $7 \mathrm{ng} \mathrm{ml}^{-1}$. Concentrations at stages 5 and 6 are similar $\left(1.4 \mathrm{ng} \mathrm{ml}^{-1}\right.$, NS, $\left.P>0.05\right)$.

\subsection{In vitro steroid production}

First spawning occurred on 10 April. Broodstock collected at the first sampling date (18 February) were at stage 2 whereas those collected at the two following sampling dates (14 and 23 March) were at stages 3 and 4, respectively. The HPLC chromatograms showed that among the peaks identified corresponding to the five references, 17,20 $\beta-\mathrm{P}$, only corresponded to a radioactive peak (Figs. 6 and 7). Other radioactive peaks were observed in both TLC migration zones analyzed, but were not investigated any further. The chromatograms concern the first female sampled at the last sampling point (end of March), whose gonad fragments were incubated for $2 \mathrm{~h}$ (Fig. 7). The same patterns were observed for the other sampling dates and the second female sampled. The three different incubation periods tested showed that $17,20 \beta-\mathrm{P}$ is produced after $30 \mathrm{~min}$ and is still present in the medium following $2 \mathrm{~h}$ of incubation, but is no longer visible after $4 \mathrm{~h}$. However, no radioactive peak corresponding to the $20 \beta-S$ reference was observed in the chromatograms (Fig. 7a) regardless of sampling date or incubation time. No significant variations were observed between the amounts of $17,20 \beta-P$ produced at the three different sampling dates. Regardless of sample analyzed, the different amounts of radioactivity found in the media were low compared to the activity of the added.
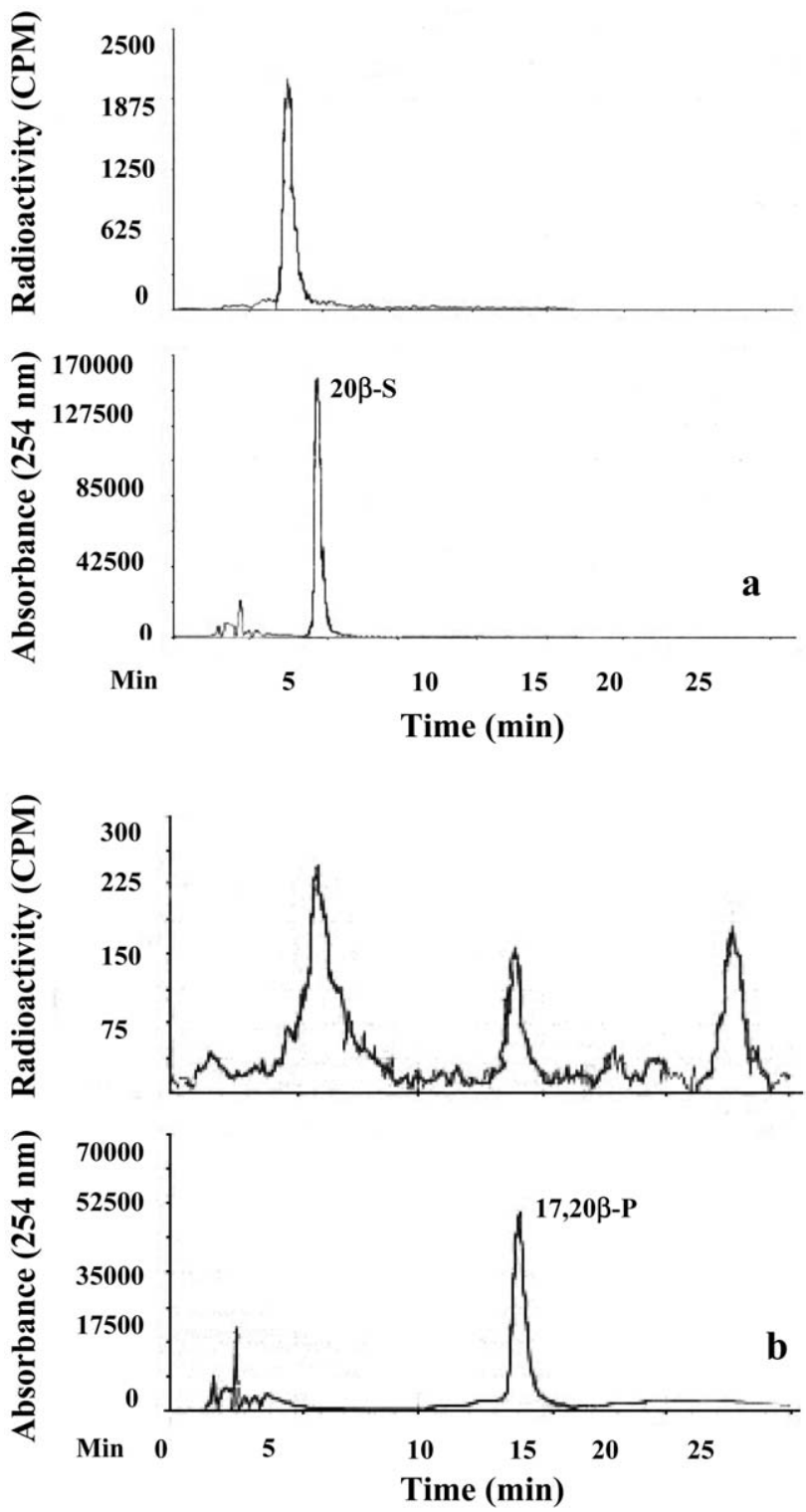

Fig. 7. HPLC radio-chromatogram of steroid metabolites synthesized by perch ovarian tissues from a fish sampled at the end of March incubated for $2 \mathrm{~h}$ with $\left[{ }^{3} \mathrm{H}\right]-17-\mathrm{P}$. Extract of incubate has been subjected to TLC and the zones corresponding to $20 \beta-\mathrm{S}$ (a) and 17,20ß-P (b), respectively, have been eluted for HPLC.

\section{Discussion}

According to Marza (1938), oogenesis in Eurasian perch is synchronous. However, in the current study, ovarian development is not synchronous between the different broodstock. This could explain the high variability observed in plasma steroid concentrations. Even though hormonal studies on animals are usually characterized by large variability, variability observed in this study was higher than that previously reported by Sulistyo et al. (1998). This is probably due to the difference of temperature profile between these two studies. Indeed, a cooling period occurred in April $1999\left(<10{ }^{\circ} \mathrm{C}\right)$ 
during the normal onset of the spawning season, possibly delaying ovarian development up to ovulation. Moreover, the individual sensitivity of the broodstock to environmental changes might be different. With respect to $17,20 \beta-\mathrm{P}$, the basic levels measured in this study were similar to those previously reported by Sulistyo et al. (1998), averaging 0.3$0.5 \mathrm{ng} \mathrm{ml}^{-1}$. However, for the first time, some significant peaks $\left(7 \mathrm{ng} \mathrm{ml}^{-1}\right)$ were assayed with individual plasma levels and averages of $3 \mathrm{ng} \mathrm{ml}^{-1}$. These levels are similar to those observed among white bass at the GVBD stage (King et al., 1995; Mylonas et al., 1997b) and slightly higher than among striped bass (Berlinsky and Specker, 1991). The sampling protocol at 2-day intervals enabled the detection of 17,20 $-\mathrm{P}$ peaks. The first significant increase occurred on 10 March while the histological observations had not shown any oocyte in the final maturational stage or with migrated $\mathrm{GV}$, but oocytes still at late vitellogenesis stage. The first prematurational oocytes corresponding to the appearance of larger lipid droplets and the beginning of the GV migration occurred on 1 April, i.e. 21 days after the first 17,20 $\beta$-P peak. No direct significant relation could be shown between the plasma steroid levels and the oocyte stage of development, with exception to the last stage, which showed significantly higher levels than stages 2 and 3 . Thus, there would seem to be some delay between the plasma 17,20ß-P increases and the effects of this steroid on the maturation of oocytes. Some high plasma 17,20 $\beta-\mathrm{P}$ contents were measured over 21 days with some high variability among the fish. This period of 21 days may correspond to the duration of the spawning period, although the 21-day delay between the first high plasma $17,20 \beta-\mathrm{P}$ levels and the histological changes (first migrating oocytes) seem to be long to be able to reach any conclusion about the role of $17,20 \beta-\mathrm{P}$ in the final oocyte maturation. Considering the fact that the first females with oocytes at stage 4 (peripheral GV stage) might not have been sampled, our results suggest that 17,20 $\beta$-P could be the MIS in Eurasian perch. As it was suggested by Haddy and Pankhurst (1999), stress exerts an inhibitory effect on gonadal steroidogenesis in fish and was shown to increase 17,20 $\beta$-P levels in blood. Confinement and sampling could have stressed the fish resulting in higher plasma 17,20ß-P levels at the beginning of the experiment.

In Morone species such as white bass or white perch, the MIS surge occurs few hours prior to the GVBD stage and the sex steroids are being quickly eliminated (King et al., 1995). In the present study, the in vitro experiment also confirmed this hypothesis, since the perch ovaries metabolize 17-P as a precursor into a small amount of $17,20 \beta-\mathrm{P}$, and not into $20 \beta-S$, during the pre-ovulatory period. Barry et al. (1995) observed the same pattern among walleye. As far as yellow perch is concerned, plasma 17,20 3 -P levels are higher in the oocytes at the GVBD stage than at the migrating GV stage (Barry et al., 1995). But 17,20ß-P levels are lower during the spawning season in percid fish compared to some salmonid fish species. In walleye, for example, higher 17,20ß-P levels are related to stage 4 (peripheral GV), but the peaks observed are 10-100 times lower than those measured in salmonid and cyprinid fish (Scott and Canario, 1987; Malison et al., 1994). Also, in percid fish, according to the results of in vitro experiments among walleye (Barry at al., 1995), the $17,20 \beta$-P requirements to induce GVBD might be low. Thus, the low levels observed at stage 5, corresponding to the GVBD stage, could be sufficient to trigger final oocyte maturation. Furthermore, as it was suggested in walleye (Scott and Canario, 1987), the 17,20ß-P might be quickly converted in non-immuno-detectable compounds such as 17,20-Psulphate or 17,20-P-glucuronate. Also, the three different incubation periods tested showed that $17,20 \beta-\mathrm{P}$ is produced after only half-an-hour and is still present in the medium following $2 \mathrm{~h}$ of incubation, but no longer detectable after $4 \mathrm{~h}$. Variations of the plasma levels may also be observed depending on the time of day at which the blood-samples were taken. A preliminary study suggested that plasma $17,20 \beta-\mathrm{P}$ levels are likely to be higher in the early morning than in the rest of the day (Migaud, unpublished data). Finally, the hypothesis would suggest that another steroid could be involved in final oocyte maturation. As far as 20ß-S is concerned, this in vitro study showed that its synthesis was not detectable at the three different durations of incubation tested, as it was observed among walleye (Barry et al., 1995). The plasma 17,20 $\beta-\mathrm{P}$ concentrations strongly increase during the 2 weeks prior to the beginning of the spawning period. These levels are significantly higher than those measured in early April. Moreover, the levels at oviposition are significantly higher than those among stages $2-4$, which would suggest another role for this steroid. Firstly, it might also be involved in spawning release and synchronization and thus may act as a pheromone, the same way in which it was demonstrated in goldfish. Secondly, the 17,20ß-P might also be involved in ovulation through prostaglandins (Goetz et al., 1989). In fact, the first ovulation stages were observed on 23 April while the plasma 17,20ß-P levels increase from 12 April.

The plasma $E_{2}$ profile observed in this study during the pre-ovulatory period, confirmed the results from Sulistyo et al. (1998). In fact, the very low plasma levels of $E_{2}$ (less than $80 \mathrm{pg} \mathrm{ml}^{-1}$ ) and $\mathrm{T}$ (less than $5 \mathrm{ng} \mathrm{ml}^{-1}$ ) during the first half of March, may be related to the end of the vitellogenic stage. Nevertheless, the comparison between plasma levels at the different stages did not show any significant differences for both steroids. Different peaks occurred over a 1-month period for both steroids, the same as for the 17,20 3 -P profile. This 1-month period corresponded approximately to the spawning period. Moreover, it was shown that $\mathrm{T}$ stimulates the effects of luteinizing hormone (LH) on 17,20ß-P synthesis in trout ovarian follicles (Jalabert and Fostier, 1984). T could play a role in the protection or the preservation of viability of the oocytes when vitellogenesis is completed, and before stage 4 (peripheral GV) (Kime, 1993).

In conclusion, these results strongly suggest a role for $17,20 \beta-\mathrm{P}$ in the final stages of ovarian development in Eurasian perch. However, the highest plasma levels were de- 
tected before any sign of oocyte maturation and following spawning. In our opinion, either the increase of 17,20 3 -P in blood would not be synchronized with the peripheral GV or GVBD stages, or that low levels could trigger final maturation and ovulation. Therefore, it would be interesting to study $17,20 \beta-\mathrm{P}$ changes inside the ovary. Besides, the highest plasma levels found at the oviposition suggest a pheromonal role. Moreover, the in vitro study showed that ovaries do not produce any $20 \beta-S$ before the maturation stages, but $17,20 \beta$-P. Unfortunately, we were not able to directly measure $20 \beta-S$ in perch blood as no label and antiserum were available. The peak levels of $\mathrm{E}_{2}$ and $\mathrm{T}$ were confirmed in spite of a strong variability, probably in relation to an unusual temperature profile.

\section{Acknowledgements}

We would like to thank all the members of the LSA laboratory staff for their active collaboration in this study as well as the Lindre Center and Matthew Sprague (Institute of Aquaculture) for comments and correction of the English text. The European Commission (FAIR-CT98-9241) partly financially supported this research.

\section{References}

Asturiano, J.F., Sorbera, L.A., Ramos, J., Kime, D.E., Carrillo, M., Zanuy, S., 2000. Hormonal regulation of the European sea bass reproductive cycle: an individualized approach. J. Fish Biol. 56, 1155-1172.

Barry, T.P., Malison, J.A., Lapp, A.F., Procarione, L.S., 1995. Effects of selected hormones and male cohorts on final oocyte maturation, ovulation, and steroid production in walleye (Stizostedion vitreum). Aquaculture 138, 331-347.

Berlinsky, D.L., Specker, J.L., 1991. Changes in gonadal hormones during oocyte development in the striped bass, Morone saxatilis. Fish Physiol. Biochem. 9, 51-62.

Berlinsky, D.L., Jackson, L.F., Smith, T.I.J., Sullivan, C.V., 1995. The annual reproductive cycle of the white bass Morone chrysops. J. World Aquac. Soc. 26, 252-260.

Borg, B., 1994. Androgens in teleost fishes. Comp. Biochem. Physiol. 109C, 219-245.

Breton, B., Fostier, A., Zohar, Y., Le Bail, P.Y., Billard, R., 1983. Gonadotropine glycoprotéique maturante et oestradiol-17 $\beta$ pendant le cycle reproducteur chez la truite fario (Salmo trutta) femelle. Gen. Comp. Endocrinol. 49, 220-231.

Cerda, J., Selman, K., Wallace, R.A., 1996. Observations on oocyte maturation and hydration in vitro in the black sea bass, Centropristis striata (Serranidae). Aquat. Living Resour. 9, 325-335.

Craig, J.F., 1977. The body composition of adult perch, Perca fluviatilis in Windermere, with reference to seasonal changes and reproduction. J. Anim. Ecol. 46, 617-632.

Dabrowski, K., Ciereszko, A., Ramseyer, L., Culver, D., Kestemont, P., 1996. Reproductive physiology of yellow perch (Perca flavescens): environmental and endocrinological cues. J. Appl. Ichthyol. 12, 139-148.

Fostier, A., Jalabert, B., Terqui, M., 1973. Action prédominante d'un dérivé hydroxylé de la progestérone sur la maturation in vitro des ovocytes de la truite arc-en-ciel, Salmo gairdnerii. C. R. Acad. Sci. Paris 277, 421-424.
Fostier, A., Weil, C., Terqui, M., Breton, B., Jalabert, B., 1978. Plasma estradiol-17ß and gonadotropin during ovulation in rainbow trout (Salmo gairdnerii). Ann. Biol. Anim. Biochim. Biophys. 18, 929-936.

Fostier, A., Breton, B., Jalabert, B., Marcuzzi, O., 1981. Evolution des niveaux plasmatiques de la gonadotropine glycoprotéique et de la $17 \alpha$ hydroxy-20ß-dihydroprogestérone au cours de la maturation et de l'ovulation chez la truite arc-en-ciel, Salmo gairdnerii. C. R. Acad. Sci. Paris 293, 817-820.

Fostier, A., Jalabert, B., 1986. Steroidogenesis in rainbow trout (Salmo gairdnerii) at various pre-ovulatory stages: changes in plasma hormone levels and in vivo and in vitro responses of the ovary to salmon gonadotropin. Fish Physiol. Biochem. 2, 87-89.

Goetz, F.W., Bergman, H.L., 1978. The effects of steroids on final maturation and ovulation of oocytes from brook trout (Salvelinus fontinalis) and yellow perch (Perca flavescens). Biol. Reprod. 18, 293-298.

Goetz, F.W., Theofan, G., 1979. In vitro stimulation of germinal vesicle breakdown and ovulation of yellow perch (Perca flavescens) oocytes. Effects of $17 \alpha$-hydroxy-20 $\beta$-dihydroprogesterone and prostaglandins. Gen. Comp. Endocrinol. 37, 273-285.

Goetz, F.W., Duman, P., Berndtson, A., Janowsky, E.G., 1989. The role of prostaglandins in the control of ovulation in yellow perch, Perca flavecsens. Fish Physiol. Biochem. 7, 163-168.

Haddy, J.A., Pankhurst, N.W., 1999. Stress induced changes in concentrations of plasma sex steroids in black bream. J. Fish Biol. 55, 1304-1316.

Jalabert, B., 1976. In vitro oocyte maturation and ovulation in rainbow trout (Salmo gairdneri), northern pike (Esox lucius), and goldfish (Carassius auratus). J. Fish. Res. Board Can. 33, 974-988.

Jalabert, B., Breton, B., Brzuska, E., Fostier, A., Wieniawsky, J., 1977. A new tool for induced spawning: the use of $17 \alpha$-hydroxy-20 $\beta$ dihydroprogesterone to spawn carp at low temperature. Aquaculture 10, 353-364.

Jalabert, B., Fostier, A., 1984. The modulatory effect in vitro of oestradiol$17 \beta$, testosterone or cortisol on the output of $17 \alpha$-hydroxy-20 $\beta$ dihydroprogesterone by rainbow trout ovarian follicles stimulated by the maturational gonadotropin s-GtH. Reprod. Nutr. Dev. 24, 127-136.

Jamet, J.L., Desmolles, F., 1994. Growth, reproduction and condition of roach (Rutilus rutilus L.), perch (Perca fluviatilis L.) and ruffe (Gymnocephalus cernuus L.) in eutrophic lake Aydat (France). Int. Rev. Hydrobiol. 79, 305-322.

Kime, D.E., 1993. Classical and non classical reproductive steroids in fish. Rev. Fish Biol. Fish. 3, 160-180.

King, W.V., Berlinsky, D.L., Sullivan, C.V., 1995. Involvement of gonadal steroids in final oocyte maturation of white perch (Morone americana) and white bass (M. chrysops): in vivo and in vitro studies. Fish Physiol. Biochem. 14, 489-500.

Le Cren, E.D., 1951. The length-weight relationship and seasonal cycle in gonad weight and condition in the perch (Perca fluviatilis). J. Anim. Ecol. 20, 201-219.

Littell, R.C., Milliken, G.A., Stroup, W.W., Wolfinger, R.D., 1996. SAS ${ }^{\circledR}$ System for Mixed Models. SAS Institute Inc, Cary, NC.

Malison, J.A., Procarione, L.S., Barry, T.P., Kapuscinski, A.R., Kayes, T.B., 1994. Endocrine and gonadal changes during the annual reproductive cycle of the freshwater teleost, Stizostedion vitreum. Fish Physiol. Biochem. 13, 473-484.

Malison, J.A., Held, J.A., 1996. Reproduction and spawning in walleye (Stizostedion vitreum). J. Appl. Ichthyol. 12, 153-156.

Malservisi, A., Magnin, E., 1968. Changements cycliques annuels se produisant dans les ovaires de Perca fluviatilis flavescens (Mitchill) de la région de Montréal. Nat. Can. 95, 929-945.

Marza, V.D., 1938. Histophysiologie de l'ovogenèse. Hermann, Paris.

Migaud, H., Fontaine, P., Sulistyo, I., Kestemont, P., Gardeur, J.N., 2002. Induction of out-of-season spawning in Eurasian perch Perca fluviatilis: effects of cooling and chilling periods on female gametogenesis and spawning. Aquaculture 205, 253-267. 
Mugnier, C., Gaignon, J.L., Fostier, A., 1997. In vitro synthesis of 17,20ß,21-trihydroxy-4-pregnen-3-one by ovaries of turbot (Scophthalmus maximus L.) during oocyte maturation. Gen. Comp. Endocrinol. 107, 63-73.

Mylonas, C., Scott, A., Zohar, Y., 1997a. Plasma gonadotropin II, sex steroids, and thyroid hormones in wild striped bass (Morone saxatilis) during spermiation and final oocyte maturation. Gen. Comp. Endocrinol. 108, 223-236.

Mylonas, C.C., Magnust, Y., Klebanov, Y., Gissis, A., Zohar, Y., 1997 b. Reproductive biology and endocrine regulation of final oocyte maturation of captive white bass. J. Fish Biol. 51, 234-250.

Mylonas, C.C., Curry Woods, L., Thomas, P., Zohar, Y., 1998. Endocrine profiles of female striped bass (Morone saxatilis) in captivity, during postvitellogenesis and induction of final oocyte maturation via controlled-release GnRHa-delivery systems. Gen. Comp. Endocrinol. 110, 276-289.

Patino, R., Thomas, P., 1990. Induction of maturation of Atlantic croaker oocytes by $17 \alpha, 20 \beta, 21$-trihydroxy-4-pregnen-3-one in vitro consideration of some biological and experimental variables. J. Exp. Zool., 97-109.

Pinter, J., Thomas, P., 1999. Induction of ovulation of mature oocytes by the maturation-inducing steroid 17,20ß,21-trihydroxy-4-pregnen-3-one in the spotted seatrout. Gen. Comp. Endocrinol. 115, 200-209.

Prat, F., Zanuy, S., Carillo, M., De Mones, A., Fostier, A., 1990. Seasonal changes in plasma levels of gonadal steroids of sea bass, Dicentrarchus labrax L. Gen. Comp. Endocrinol. 78, 361-373.

Rinchard, J., Kestemont, P., Kühn, E.R., Fostier, A., 1996. Comparative study of reproductive biology in single and multiple spawner cyprinid fish. I. Morphological and histological features. J. Fish Biol. 49, 883-894.
Rocha, M.J., Ries-Henriques, M.A., 1998. Steroid metabolism by ovarian follicles of the tilapia Oreochromis mossambicus (Teleostei, Cichlidae). Comp. Biochem. Physiol. 121B, 85-90.

Scott, A.P., Canario, A.V., 1987. Status of oocyte maturation inducing steroids in teleosts. In: Idler, D.R., Crim, L.W., Walsh, J.M. (Eds.), Proceedings of the Third International Symposium on the Reproductive Physiology of Fish. St. John's Memorial University Press, pp. 224-234.

Scott, A.P., Canario, A.V., 1992. 17 $\alpha, 20 \beta$-dihydroxy-4-pregnen-3-one 20-sulfate: a major new metabolite of the teleost oocyte maturationinducing steroid. Gen. Comp. Endocrinol. 85, 91-100.

Sulistyo, I., Rinchard, J., Fontaine, P., Gardeur, J.N., Capdeville, B., Kestemont, P., 1998. Reproductive cycle and plasma levels of sex steroids in female Eurasian perch Perca fluviatilis. Aquat. Living Resour. 11, 101-110.

Sulistyo, I., Fontaine, P., Rinchard, J., Gardeur, J.N., Migaud, H., Capdeville, B., Kestemont, P., 2000. Reproductive cycle and plasma levels steroids in male Eurasian perch Perca fluviatilis. Aquat. Living Resour. 13, 99-106.

Thomas, P., Trant, J.M., 1989. Evidence that 17 $\alpha, 20 \beta, 21$-trihydroxy-4pregnen-3-one is a maturation-inducing steroid in spotted seatrout. Fish Physiol. Biochem. 7, 185-191.

Trant, J.M., Thomas, P., Shackleton, C.H.L., 1986. Identification of $17 \alpha, 20 \beta, 21$-trihydroxy-4-pregnen-3-one as the major ovarian steroid produced by the teleost Micropogonias undulatus during final oocyte maturation. Steroids 47, 89-99.

Treasurer, J.W., Holliday, F.G.T., 1981. Some aspects of the reproductive biology of perch Perca fluviatilis L. A histology description of the reproductive cycle. J. Fish Biol. 18, 359-376. 